\title{
FACTORS ASSOCIATED WITH HOSPITAL PERFORMANCE IN THE IMPLEMENTATION OF DIRECT OBSERVED TREATMENT SHORT-COURSE STRATEGY FOR TUBERCULOSIS CONTROL IN CENTRAL JAVA
}

\author{
Yusniar Ramadhiana'), Yusup Subagio Sutanto',2), \\ Ari N Probandari2), Reviono',2) \\ 1)Dr. Moewardi Hospital, Surakarta \\ 2)Faculty of Medicine, Universitas Sebelas Maret
}

\begin{abstract}
Background: Tuberculosis (TB) is a major health problem worldwide. The TB epidemic is larger than previously thought. Lung hospitals and clinics contribute significantly to the number of patients from all smear positive cases. This study aimed to examine factors associated with hospital performance in the implementation of Direct Observed Treatment Short-Course Strategy (DOTS) for tuberculosis control in Central Java.

Subjects and Method: A retrospective cohort study was conducted in Central Java. A total of 158 hospitals that implemented DOTS strategy were selected for this study. The dependent variable was hospital performance. The hospital performance in TB control was evaluated by success rate of treatment. The independent variables were DOTS team commitment and organization of hospitals, treatment, treatment supervision, internal/external networks, and health facility.

Results: As many as 110 hospitals completed data. There was no significant relationship between DOTS team commitment, organization of hospitals, supervision, internal/external networks, health facility, with work hospital performance. The type of hospital was significantly related to the work hospital performance with the lower type of hospital showed better hospital performance.

Conclusion: DOTS team commitment, organization of hospitals, supervision, internal/external networks, and health facility, do not have significant association with hospital performance.
\end{abstract}

Keywords: tuberculosis, DOTS, hospital performance.

\section{Correspondence:}

Yusniar Ramadhiana. Dr. Moewardi Hospital, Surakarta, Central Java.

Email: yramadhiana@gmail.com. Mobile: 082328045532. 